\title{
Economic Problems and Loneliness as Factors Related to Subjective Unmet Health Needs in People with Chronic Diseases and Dependency
}

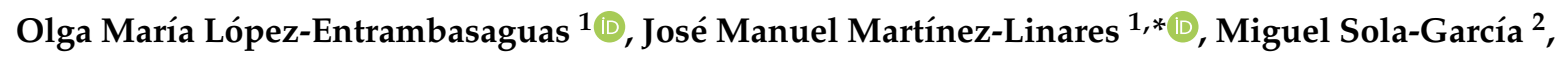 \\ Carmen García-Redecillas ${ }^{2}$ and Ana María Díaz-Meco-Niño ${ }^{2}$ \\ 1 Department of Nursing, Universidad de Jaén, 23071 Jaén, Spain; omlopez@ujaen.es \\ 2 Complejo Hospitalario de Jaén, Servicio Andaluz de Salud, 23007 Jaén, Spain; \\ misola1989@gmail.com (M.S.-G.); garciaredecillas@gmail.com (C.G.-R.); \\ adimeni64@hotmail.com (A.M.D.-M.-N.) \\ * Correspondence: jmlinare@ujaen.es; Tel.: +34-953-217-636
}

Received: 9 March 2020; Accepted: 22 April 2020; Published: 23 April 2020

check for updates

\begin{abstract}
Background: The continuous increase of people with chronic diseases is one of the greatest challenges for healthcare systems worldwide. Population growth and life expectancy means that an increasing number of people with chronic diseases and dependency need some kind of assistance to meet their needs. Determining these subjective unmet needs helps to understand the situation of these people. The aim of this study was to explore the perceptions of chronic patients over 65 years of age from the day-care center toward subjective health needs that are not being met by the socio-health system. Methods: Qualitative exploratory-descriptive study. Through convenience sampling, we selected people with chronic diseases and dependency who used day-care centers and met the inclusion criteria. Focus groups were performed. The data were transcribed and a thematic analysis was carried out using Atlas.ti software. Results: The topics resulting from the analysis were classified into dissatisfaction of biological/physiological needs, psychological needs, social needs, and other issues that arose in both groups of participants which referred to the types of needs previously indicated. The issues related to social and psycho-social needs stood out. Conclusions: People with chronic diseases and dependency have their physiological needs covered with the help they receive, but their situation of dependency generates additional costs that worsen their economic situation. However, their greatest need is due to the loneliness they feel and the feeling they have of "being a burden" on their families.
\end{abstract}

Keywords: needs assessment; disabled persons; qualitative research; chronic disease; home nursing; vulnerable population

\section{Introduction}

The healthcare systems of developed countries are facing the challenge of providing attention to an increasing number of people with chronic diseases, due the increase of life expectancy and the aging of the population caused by the decrease in birth rates. A chronic disease is any long-term health issue and, generally, of slow progression [1]. According to a study at the European scale, Switzerland is the country with the best data about chronic diseases and Belgium is the opposite end of the rank [2]. These data can be extrapolated at the international level, which is why the World Health Organization has proposed the goal of reducing the premature mortality by chronic diseases by $25 \%$ in the year 2025 , under the " $25 \times 25$ " motto [3].

The data provided by the European Health Interview Survey of 2014 [4] indicate that $59.83 \%$ of the Spanish population over 15 years of age suffer from a chronic disease, with the most frequent 
diseases being high blood pressure (18.74\% of cases), hypercholesterolemia $(16.70 \%)$, chronic cervical pain $(16.52 \%)$, chronic low back pain $(19.22 \%)$, diabetes mellitus $(6.84 \%)$, and chronic respiratory diseases $(3.32 \%)$.

The condition of being chronically ill produces common consequences among those who suffer from it: difficulty in decision-making, mood alteration, communication problems in the doctor-patient relationship and in the family, labor and social scope, lack of adherence to treatments or medical guidelines, feeding problems, alteration of the physical functions, lack of physical activity, fatigue, and difficulties with pain management, among others [5,6].

Both the increase of the rate of chronic diseases and their causes have raised the number of people in a situation of dependency. That is, there is a larger number of elderly people with greater risk of suffering from chronic diseases, which can trigger complications that such people survive, although leaving them in a situation of dependency [7]. This creates a relationship between chronic diseases and dependency, giving rise to the existence of people with chronic diseases and dependency (PCDD).

In the year 2019, the rate of dependency in the Spanish population was $54.28 \%$, which had increased continuously since the year 2008 [8]. In the case of people over 64 years of age, this rate was $29.94 \%$, also with a positive increase since 2008 [9]. Day-care centres are part of the assistance offer for people with dependency. There are 3387 day-care centers in Spain, with the capacity to attend to a total of 90,577 people. Sixty percent of the assistance is financed with public funds, and 72,897 of the people attended in these centers are PCDD [10].

From the healthcare perspective, the most important subjective unmet needs are those perceived by people with chronic diseases, since they can cause delays in the reception of healthcare services and, in turn, worse health results [11]. Therefore, determining the relationship between the unmet healthcare needs and the adverse results is important from the point of view of healthcare service provision, since the detection and removal of potentially modifiable barriers to attention may improve the health results. However, there is limited and inconsistent evidence on the relationship between the needs that are not satisfied by the healthcare system and the health results [12].

Some previous works have associated subjective unmet needs with an increase in the visits to emergency services [13,14], whereas other studies show inconclusive data of the rates of hospital admission and general visits to the doctor within the general population [15]. Few studies have addressed the effect of unmet needs and their consequences in a high-risk population of patients with chronic diseases. A study on such needs is fundamental to perform a diagnosis of the situation, as well as to establish what services and attention are being provided, which of these are adequate, and whether there are deficiencies, regarding PCDD.

A study on subjective unmet needs is fundamental to know the services that are being provided, the ones that are most adequate and their deficiencies, from the perspective of PCDD. Therefore, unravelling the subjective unmet needs of these people will allow developing programs and strategies designed to that end and, thus, contributing to improving the results in health and quality of life and to promoting a better use of social and healthcare services.

The aim is to explore the perceptions of PCDD over 65 years of age and who are users of day-care centers toward subjective healthcare needs that are not being satisfied by the social health system.

\section{Materials and Methods}

The methodology used in this study is presented in the Consolidated Criteria for Reporting Qualitative Research (COREQ) format [16] for qualitative studies.

\subsection{Research Team and Flexibility}

The members of the research team had the following training: J.M.M.L. (male), nurse and doctor; O.M.L.E (female), nurse and doctor; M.S.G (male), family physician and doctor; C.G.R. (female), geriatric specialist physician; A.M.D.N. (female), nurse and doctorate student. During the study period, J.M.M.L. and O.M.L.E. worked as faculty members, M.S.G. and C.G.R. as a family physician and 
a geriatric specialist physician, respectively, and A.M.D.N. as a nurse. All the members of the research team had research training and they all had previously participated in both quantitative and qualitative research projects. None of the research team members had any kind of relationship or previous contact with the participants of the study. The latter were informed about the composition of the research team and about the aim and interest of the study when they were offered to participate in it.

\subsection{Study Design}

A descriptive-exploratory qualitative study was carried out. This is the most suitable methodology due to the complexity of the aim of the study and the difficulty in measuring the concepts [17], and it allowed obtaining the subjective perception of the participants [18]. This methodological approach is based on the principles of naturalistic observation, which aims to study individuals in their natural state [19]. Through convenience sampling, we recruited PCDD who met the following inclusion criteria: to have a moderate (40-55 points) or severe (20-35 points) degree of dependency according to the Barthel Index [20], translated into Spanish [21]; to be a user of a day-care center, where the contact with and recruitment of the participants took place, and to have no cognitive deterioration. The Barthel Index is a validated instrument that allows assessing the level of dependency of a person to carry out basic activities of daily living, assigning scores based on his/her capability.

The sample was composed of a total of 23 PCDD from the localities of Martos and Mancha Real (Jaén, Spain) (17 people of Martos and 6 people of Mancha Real). The data gathering was conducted in a designated room in the day-care centers of these localities. No additional people other than the participants and the members of the research team were present during the data-gathering process.

The main characteristics of the participants are detailed in Table 1. 
Table 1. Sociodemographic characteristics of the sample of people with chronic diseases and dependency (PCDD).

\begin{tabular}{|c|c|c|c|c|c|c|c|c|c|c|}
\hline Code & Sex & Age (Years) & Chronic Pathologies & Evolution Years & $\begin{array}{l}\text { Degree of Dependency } \\
\text { (Barthel Index Score) }\end{array}$ & $\begin{array}{l}\text { Recognition of Situation } \\
\text { of Dependency * }\end{array}$ & Assigned Carer & Civil State & Number of Children & $\begin{array}{l}\text { Lives Alone or with } \\
\text { One or More People }\end{array}$ \\
\hline GF1PC-P1 & Male & 89 & $\begin{array}{l}\text { Parkinson's disease and } \\
\text { polyarthrosis }\end{array}$ & 37 & Moderate (55) & Yes & Yes & Widow & 3 & Alone \\
\hline GF1PC-P2 & Female & 84 & Polyarthrosis & 8 & Moderate (55) & Yes & Yes & Widow & 2 & Alone \\
\hline GF1PC-P3 & Female & 84 & Stroke and cardiopathy & 7 & Moderate (45) & No & Yes & Widow & 4 & Alone \\
\hline GF1PC-P4 & Female & 86 & Polyarthrosis & 32 & Moderate (55) & Yes & Yes & Widow & 3 & Alone \\
\hline GF1PC-P5 & Female & 91 & $\begin{array}{l}\text { Parkinson's disease and } \\
\text { polyarthrosis }\end{array}$ & 10 & Moderate (55) & Yes & Yes & Widow & 1 & Alone \\
\hline GF1PC-P6 & Female & 82 & Miastenia gravis and DR & 12 & Moderate (55) & Yes & Yes & Widow & 3 & Alone \\
\hline GF1PC-P7 & Male & 89 & Polyarthrosis and UI & 11 & Moderate (55) & No & No & Widow & 1 & Alone \\
\hline GF1PC-P8 & Female & 76 & Stroke & 13 & Severe (35) & Yes & Yes & Widow & 4 & Alone \\
\hline GF2PC-P1 & Female & 85 & Polyarthrosis & 10 & Severe (20) & Yes & Yes & Married & 3 & Not alone \\
\hline GF2PC-P2 & Female & 81 & Polyarthrosis and UI & 10 & Moderate (55) & No & No & Widow & 4 & Alone \\
\hline GF2PC-P3 & Female & 84 & Stroke & 12 & Severe (25) & Yes & Yes & Widow & 3 & Alone \\
\hline GF2PC-P4 & Female & 87 & Stroke & 8 & Moderate (55) & No & No & Widow & 4 & Alone \\
\hline GF2PC-P5 & Female & 80 & COPD and cardiopathy & 7 & Moderate (55) & No & No & Widow & 4 & Not alone \\
\hline GF2PC-P6 & Male & 91 & Polyarthrosis and cardiopathy & 11 & Moderate (55) & No & Yes & Widow & 5 & Alone \\
\hline GF2PC-P7 & Female & 91 & Polyarthrosis and cardiopathy & 8 & Moderate (55) & No & Yes & Widow & 2 & Alone \\
\hline GF3PC-P1 & Female & 83 & Polyarthrosis and cardiopathy & 7 & Moderate (55) & Yes & Yes & Married & 4 & Not alone \\
\hline GF3PC-P2 & Female & 84 & Stroke & 6 & Moderate (55) & Yes & Yes & Widow & 1 & Not alone \\
\hline GF3PC-P3 & Female & 78 & COPD and cardiopathy & 10 & Moderate (55) & No & Yes & Married & 2 & Not alone \\
\hline GF3PC-P4 & Female & 84 & Polyarthrosis & 12 & Moderate (55) & No & Yes & Married & 3 & Not alone \\
\hline GF3PC-P5 & Female & 82 & COPD and DR & 30 & Moderate (55) & Yes & Yes & Married & 5 & Not alone \\
\hline GF3PC-P6 & Female & 85 & COPD and polyarthrosis & 12 & Moderate (50) & Yes & No & Widow & 2 & Alone \\
\hline GF3PC-P7 & Male & 84 & Stroke & 9 & Moderate (50) & No & No & Married & 2 & Not alone \\
\hline GF3PC-P8 & Female & 90 & Polyarthrosis and cardiopathy & 15 & Moderate (55) & No & Yes & Widow & 2 & Alone \\
\hline
\end{tabular}

Abbreviations: COPD, chronic obstructive pulmonary disease; UI, urinary incontinence; PCDD, people with chronic diseases and dependency; DR, diabetic retinopathy. * Recognition of the situation of dependency according to Law 39/2006, of December 14th, on the Promotion of Personal Autonomy and Attention to People in a Situation of Dependency [22]. Source: developed by author. 
Three focus groups were performed (two in Martos and one in Mancha Real) in April and May 2019, with which data saturation was reached [23]. The ad hoc script of questions was designed to obtain the information required to respond to the proposed objective, and it was created and revised by all the members of the research team. A pilot focus group was conducted with three PCDD in March 2019. Then, some questions were re-written, added, or removed, resulting in the final version of the script. Table 2 shows the main questions included in the focus groups and in the interviews.

Table 2. Main questions asked in the focus groups and interviews with PCDD.

\begin{tabular}{|c|c|}
\hline Pre-Established Categories & Questions for PCDD \\
\hline Basic needs & $\begin{array}{c}\text { Do you think your basic needs are met (eating, dressing, moving, going to the toilet ... ) } \\
\text { What help do you require for these to be satisfied? }\end{array}$ \\
\hline Attention provided by the carer & $\begin{array}{l}\text { What are the tasks of the carer in your home? } \\
\text { Do you think that the time the carer spends in your home is enough to meet your needs? } \\
\text { Do you think that the carer is sufficiently prepared to attend to both your daily needs and emergency } \\
\text { situations that may occur in your home? }\end{array}$ \\
\hline $\begin{array}{l}\text { Availability of assistance material } \\
\text { in the patient's home }\end{array}$ & $\begin{array}{l}\text { Do you have any sort of sanitary and/or assistance material in your home due to your chronic disease? } \\
\text { If so, has it been provided by the Social Security or social services, or did you have to buy it? } \\
\text { Do you think that the material you have is enough or do you require further material? If so, which material? }\end{array}$ \\
\hline Bureaucratic management and processes & $\begin{array}{c}\text { Do you need somebody to perform these processes? Who is that person: relative, carer, neighbor, friend? } \\
\text { Why do you need this kind of help? } \\
\text { What perception do you have toward the difficulty of carrying out these processes? }\end{array}$ \\
\hline Personal and family economy & $\begin{array}{l}\text { Would you rate your current economic situation as worse, same or better with respect to when your } \\
\text { chronic disease began? } \\
\text { If there is a difference, what do you think this difference may be due to? } \\
\text { Do you think that your chronic disease has deteriorated your economic situation? }\end{array}$ \\
\hline Other needs & $\begin{array}{l}\text { Apart from the personal, material and emotional/social needs, what other needs do you have as chronic } \\
\text { patients that have not been mentioned yet? }\end{array}$ \\
\hline
\end{tabular}

None of the focus groups had to be repeated. All of them were recorded in audio, and field notes were taken, which were also incorporated in the data analysis. The duration of the focus groups was in the range of $1.5-2.5 \mathrm{~h}$ (including some breaks). The transcriptions were not given to the participants, since they did not want to revise them.

\subsection{Data Analysis and Results}

The coding of the transcriptions was conducted individually by two researchers, who then unified their encoded transcriptions to produce the final coding [24]. The content of the transcriptions was analyzed following the method of the six phases of thematic analysis with scientific rigor described by Braun and Clarke (familiarization with the data, generation of initial categories or codes, theme search, theme revision, definition and naming of themes, and writing of the final report) [25], as well as the process to ensure the reliability of the results described by Nowell et al. [26]. The codes that were related to each other were grouped in categories, from which subthemes emerged, which in turn were grouped to produce the final themes. This qualitative analysis of data was conducted using Atlas.ti v.5 for Windows ${ }^{\circledR}$ (ATLAS.ti Scientific Software Development GmbH, Berlin, Germany). The results were not sent to the participants for revision.

\subsection{Ethical Considerations}

The study was carried out following the ethical principles of the Declaration of Helsinki. The treatment of personal data was performed in compliance with Regulation 2016/679 of the European Parliament and the Council of April 27th 2016, on the protection of natural persons with respect to the treatment of personal data and the unrestricted movement of such data, which revokes Directive 95/46/CE. 
This study was conducted after obtaining the approval from the Ethics Committee of the University of Jaén. Each participant was requested to sign the corresponding informed consent.

\section{Results}

The generated themes were classified into the following categories: biological needs, psychological needs, social needs, and socioemotional needs.

\subsection{Biological Needs Results}

The results related to the biological needs of PCDD did not include the existence of unmet physiological needs, such as eating, going to the bathroom, moving, or sleeping, among others; these results referred to the needs of assistance material to satisfy this type of needs (Table 3).

Table 3. Theme, subthemes, and codes related to the satisfaction of biological needs of PCDD.

\begin{tabular}{|c|c|c|}
\hline Theme & Subtheme & Codes \\
\hline \multirow{2}{*}{ Needs of assistance material } & Assistance material provided by public services & $\begin{array}{c}\text { Assistance material provided } \\
\text { Walking frames provided } \\
\text { Wheelchairs provided } \\
\text { Other assistance material provided } \\
\text { Contribution for better quality material }\end{array}$ \\
\hline & Unmet needs related to assistance material & $\begin{array}{l}\text { Assistance material not provided } \\
\text { Assistance material to purchase } \\
\text { Adjustable beds not provided } \\
\text { Cranes not provided } \\
\text { Other assistance material not provided }\end{array}$ \\
\hline
\end{tabular}

Source: developed by author.

Therefore, a theme emerged about the needs of assistance material to carry out basic daily life activities or to satisfy physiological needs. The PCDD had assistance material provided by the public healthcare system, such as walking frames, wheelchairs, and crutches.

"Is that walking frame yours? No, the government gave it to me when I got that thing in my leg and I could no longer walk on my own"

\section{(GF2PC-P2)}

"And do you have a wheelchair at home, or a walking frame ... ? I have been in this wheelchair for four years, which was given to me by the Social Security"

\section{(GF1PC-P5)}

However, some material is not provided by the public healthcare system in cases of extreme need, such as articulated beds, and an extra price must be paid to obtain material of better quality than that provided by the government.

"My daughter, who is the one who takes care of me, finds it hard to move me. She talked to the people at the Social Security to see if they can give us a bed... They told her that that is for people who are permanently in the bed. But it is very hard for her to move me! And I suffer, because I see that she struggles ..."

\section{(GF1PC-P6)}

"I did get a wheelchair, and the walking frame too, but I paid a little extra and I got this one, which is better"

(GF3PC-P4) 


\subsection{Results Related to Psychological Needs}

The participants perceived that, emotionally, they had experienced a series of changes that generated a series of needs, since they felt that they had lost the authority they once had, they refuse to leave their homes and, above all, they feel lonely and sad (Table 4).

Table 4. Theme, subthemes, and codes related to the satisfaction of psychological needs of PCDD.

\begin{tabular}{|c|c|c|}
\hline Theme & Subtheme & Codes \\
\hline \multirow{3}{*}{ Emotional needs } & Loss of authority & $\begin{array}{c}\text { Feels unheeded } \\
\text { No solutions are offered to solve his/her problems } \\
\text { His/her opinion does not count } \\
\text { His/her relatives decide for him/her }\end{array}$ \\
\hline & Clinging on to their homes & $\begin{array}{c}\text { Does not want to leave his/her home } \\
\text { Misses his/her home } \\
\text { Moving to a different home } \\
\text { Periods in the homes of his/her different children }\end{array}$ \\
\hline & Loneliness and sadness & $\begin{array}{l}\text { Feeling of sadness } \\
\text { Feeling of loneliness } \\
\text { Nostalgia for times past } \\
\text { Nobody visits him/her }\end{array}$ \\
\hline
\end{tabular}

Source: developed by author.

The participants perceived that they had lost the authority that they used to have in the past, since they think that the socio-sanitary system does not attend to their demands and does not consider their opinions. Other people make the decisions for them, and they can even find this offensive.

"Offended, I feel offended. They don't listen to me!"

\section{(GF1PC-P1)}

"The cardiologist tells me: Make sure they don't give you a different medicine; they must give you the same one! Then why do they change it in the pharmacy after I already told them?"

(GF3PC-P2)

These people cling on to the idea of staying in their homes. Those who had moved out highlighted that they missed living in their own place.

"I loved being in my house ... (now she lives with her daughter)"

(GF1PC-P3)

"My daughter tells me that I should move in with them. But they are working! They leave at 7 in the morning and come back at 3 in the afternoon! What do I do in their house alone? I'm better off in my house"

\section{(GF1PC-P4)}

In this regard, there was a generalized feeling of being "at ease" during the time they spend in the day-care center, although they were also concerned about being a burden on their children, which leads them to prefer being alone in their own homes.

"They treat me very well in this centre... That's all I can say"

(GF2PC-P3) 
"We need more attention from our relatives, but then they can't have a normal life. They help me with everything I do, but I don't want to be a burden on them, because I suffer when I see that they can't do what they want to do or go wherever they would like to go because of me"

(GF1PC-P1)

Lastly, the participants described a series of shared feelings, which are not attended to from the public socio-sanitary system. These are related to sadness, nostalgia, and especially loneliness.

"It's not the same anymore. When my husband was alive, we used to go traveling, and sometimes our children came with us..."

(GF3PC-P4)

"I think I need somebody who could be with me at times, to go for walks ... I feel very lonely!"

(GF2PC-P4)

\subsection{Results Related to Social Needs}

Most of the needs mentioned in the analysis of the results were related to the social sphere of the PCDD. All of them were grouped into two themes: economic unmet needs and critiques on the socio-sanitary system (Tables 5 and 6).

Table 5. Theme, subthemes, and codes related to the satisfaction of social needs of PCDD.

\begin{tabular}{|c|c|c|}
\hline Theme & Subtheme & Codes \\
\hline \multirow{3}{*}{ Economic unmet needs } & Loss of control on their own economy & $\begin{array}{l}\text { Does not know the expenses } \\
\text { His/her relatives manage his/her economy } \\
\text { Does not control his/her expenses }\end{array}$ \\
\hline & $\begin{array}{l}\text { The situation of dependency generates } \\
\text { additional expenses }\end{array}$ & $\begin{array}{l}\text { Day-care center expense } \\
\text { Expense for hiring private home assistance } \\
\text { Pension is not raised with dependency } \\
\text { Paying for home assistance } \\
\text { Cannot help his/her children financially }\end{array}$ \\
\hline & Lack of public aids & $\begin{array}{l}\text { Complains about the lack of public aid } \\
\text { Would spend more in private assistance if he/she could afford it } \\
\text { Children cannot help financially }\end{array}$ \\
\hline
\end{tabular}

Source: developed by author.

Table 6. Theme, subthemes, and codes related to the satisfaction of social needs of PCDD (continuation).

\begin{tabular}{|c|c|c|}
\hline Theme & Subtheme & Codes \\
\hline \multirow{3}{*}{ Critiques on the socio-sanitary system } & $\begin{array}{l}\text { Critiques on the social } \\
\text { benefit system }\end{array}$ & $\begin{array}{c}\text { Benefits for the basics } \\
\text { Delayed reception of benefits } \\
\text { No effective solutions are offered } \\
\text { People who do not receive home assistance }\end{array}$ \\
\hline & $\begin{array}{l}\text { Critiques (and compliments) } \\
\text { on the healthcare system }\end{array}$ & $\begin{array}{l}\text { Good treatment but not enough staff } \\
\text { Complaints about the assistance received } \\
\text { Delayed visits from the specialists }\end{array}$ \\
\hline & $\begin{array}{l}\text { Critiques (and compliments) } \\
\text { on the caregivers }\end{array}$ & $\begin{array}{l}\text { Carer with work overload } \\
\text { Carer who is well-trained to do their job } \\
\text { People who do not have a home carer } \\
\text { Carer who cannot go beyond his/her capacity } \\
\text { Carer who knows how to do his/her job }\end{array}$ \\
\hline
\end{tabular}

Source: developed by author.

With respect to finances, the participants usually lose control on their personal and home economy, and it is their children who take such control, as well as control of the rest of the bureaucratic processes that need to be done. This was highlighted by the PCDD in the questions related to the expenses that could derive from their situation. 
"My children manage everything related to money. I ask them and they tell me that everything is paid through the bank. And the water and electricity bills and all that... my children arranged everything to be paid through the bank, and they manage my accounts"

(GF2PC-P5)

The participants perceived that they had one or more chronic diseases that generate a moderate or severe degree of dependency, with the subsequent additional expenses. Some of these expenses are the copayment of the day-care center and the need to hire an informal caregiver in addition to the one who, sometimes, is provided by the public administration. This assistance does not cover their daily needs and they must hire such service privately, usually through informal caregivers with no training. If their pensions would increase, they stated that such increase would be assigned to help their children economically in order for them to have more time to be with them, and to hire informal caregivers to meet their needs.

"I have to pay a woman to take care of me, and I also have to pay the day-care centre-How much do I have to pay? I don't know. I pay through the bank, but I know that I have to pay for things that I wouldn't have to if I wasn't in this state"

(GF2PC-P6)

Therefore, the PCDD perceived that their diseases affected them economically and that there is a lack of public aid to improve their situation.

"Do you think a couple can live on a pension of $800 €$ ? We have to pay electricity, water, this day-care centre ... We don't have enough resources!"

(GF3PC-P1)

There were a series of critiques on the current socio-sanitary system related to three specific scopes: social benefit system, healthcare system, and caregivers. Firstly, in their opinion, the current system of social benefits does not provide a solution to their problem and some people do not get the help they need; some people wait a long time to receive such help.

"We have been waiting for four years to get this help ... but it just doesn't arrive"

(GF2PC-P6)

"I only want one of those beds. It would be of great help for my daughter when she has to move me.

That's all I'm asking for"

(GF1PC-P6)

Secondly, the participants expressed their critiques, and compliments, on the attention provided to them by the public healthcare system when they make use of it. Their complaints were focused on the lack of material and professional resources with which this system attends to them. However, they highlighted the good treatment they received from the health personnel who attended to them. To this respect, the management of medical visits and revisions is assumed by their children or carers.

"No, it's not enough with the people available to provide attention. They treat us well, but there should be more professionals in the day-care centre when we go there"

(GF3PC-P1)

"My children get the prescriptions for me ... for the diapers and medicines I need and all that" (GF1PC-P4)

Lastly, the participants also expressed critiques on the attention they receive from the caregivers provided by social services, since some PCDD felt disgraced for not having such support personnel. However, they also believed that these professionals are well-trained to carry out their job, which they do the best way they can. 
"That person comes three days per week. She helps me with whatever I can't do on my own. She helps me with my medicines and my shopping bags ... she helps me with the house ... because I can't do it myself anymore"

(GF2PC-P4)

\subsection{Results Related to Psychosocial Needs}

The participants also talked about their psychosocial needs and the relationship between them and their families. The two subthemes generated from this theme were the relief they get from the fact that their relatives take care of their bureaucratic processes and their perception of being a "burden" on their children, which appears again, tackling their family relationships (Table 7).

Table 7. Theme, subthemes, and codes related to the satisfaction of psychosocial needs of PCDD.

\begin{tabular}{|c|c|c|}
\hline Theme & Subtheme & Codes \\
\hline \multirow[b]{2}{*}{ Family relationship } & Solved bureaucratic processes and management & $\begin{array}{l}\text { His/her relatives do the paperwork } \\
\text { His/her relatives solve his/her bureaucratic problems } \\
\text { Unconcern about paperwork } \\
\text { Does not know how to solve bureaucratic problems }\end{array}$ \\
\hline & Feeling of being a "burden" & $\begin{array}{l}\text { Relatives with little time to attend to them } \\
\text { His/her situation affects his/her family members } \\
\text { Does not want to be a nuisance } \\
\text { Perceives him/herself as a burden } \\
\text { Would like to need no help }\end{array}$ \\
\hline
\end{tabular}

Source: developed by author.

The processes and paperwork that PCDD need to perform are managed and solved by their relatives, who, sometimes, must make decisions for them, which increases the perception of authority loss, as was previously mentioned.

Furthermore, as was stated in their unmet emotional needs, PCDD had the feeling of being a "burden" on their children. The latter are committed to their care, but their children have other obligations that prevent them from providing them all the attention they need. That is what leads PCDD to hire private informal caregivers or the services of a day-care center. All this causes the situation of chronic disease and dependency to have an impact on the family and economy of the people who suffer from it.

\section{Discussion}

The World Health Organization defines health as "a state of complete physical, mental and social well-being, and not only the absence of affectations or diseases" [27]. However, the models from which health is approached have changed, that is, from the Biomedic Model, which reduces disease to the deviation of a series of biological (physiological) variables, to the Biopsychosocial Model proposed by Engel [28], which is framed within the General Systems Theory and for which there are multiple causes of health that comprise the biological, psychological, and social spheres of the individual. From this basis, the present study was focused on exploring the subjective unmet healthcare needs of PCDD, addressing those three spheres that influence the individual and his/her health.

The care that PCDD require to satisfy their healthcare needs has changed in the last years with regard to the person who provides it. In the last 20 years, the number of potential carers per PCDD has decreased from 15 in the year 1998 to 9 in the year 2018. In the case of carers aged 40-64 years, $85 \%$ are women, although this gender breach inverts with older carer age, which is up to $75 \%$ males in the group of carers of 90 years of age and older [29].

The different European countries have systems of attention to dependence based on four models: liberal model (British Islands), Nordic model, corporate model (Central European countries), and Mediterranean model. However, they all share a series of characteristics, such as the fact that they 
do not replace the work performed by the families of PCDD, they provide economic aid, residential attention, and home services, they are publicly regulated and funded, and the users participate in the financing of these services [30].

The participants did not mention the existence of unmet biological or physiological needs, such as eating, washing up, moving, etc. They had the help of formal and/or informal caregivers and relatives to cover those needs. In this scope, the demand was related to the acquisition of complex material of technical aid (mainly adjustable beds and cranes) and assistance to make the necessary adjustments in the home of the PCDD in order to be able to use other technical aid that require more space [31]. Simpler technical aid is easily and quickly provided (walking frames, crutches, wheelchairs, etc.), but more complex technical aid and home adjustments are more slowly provided. All this technical assistance would help the person or his/her carer to satisfy this type of needs.

In the psychological sphere, the participants detected that their situation made them lose the authority they had in the past. This perception was shared and is reported in other studies, even in people who are not in a situation of dependence. An example of this is the qualitative study conducted with people in a situation of pre-retirement aged between 50 and 65 years, who described a loss of authority to their children, since their provider role deteriorated and they had to rely on other factors such as complicity, sharing daily moments more often and participating in the home tasks more frequently [32]. The retirement age seems to be the moment when the loss of authority of a person begins, since the fact of being no longer productive and useful is not limited to the social scope, as it also involves the family sphere.

The authority of age is losing relevance due to the fact that the importance of elder people as passers of culture for the younger generations is decreasing; the oral information that these people used to transmit has been replaced with mass communication through the use of new technologies, and elder people have been isolated, with many of them being moved to hospices [33]. Culturally, society has shifted from a model based on family values and the recognition of the authority of elder people to a more recent model based on economic growth, constant change, and consumption [34].

However, the most relevant subtheme derived from the analysis, with a generalized consensus, was the loneliness that these people feel, which has become an endemic harm of the society of developed countries. In Spain, $43.1 \%$ of the homes are inhabited by a person of 65 years of age or older who lives alone; that is, 2 million people are in such situation [35]. This means $3.9 \%$ more with respect to the previous year. Although there are elder people who prefer to live alone, which can be an indicator of success, independence, and well-being, many others live this loneliness with anxiety.

Unwanted loneliness affects the health and quality of life of elder people. People who live alone unwillingly can have a higher risk of premature death, by up to $14 \%$ [36], since feeling alone is worse than being alone [37], and loneliness is an important factor to understand the development of mental health problems in this population [38].

On the other hand, other elders decide to live alone to avoid the feeling of being a "burden" to their children [39], although there are more causes that contribute to such perception, such as the increase of expenses derived from a certain degree of dependence [40], the perception of the deterioration of their quality of life and the loss of autonomy [41], and the belief that they interfere with the work and social life of their relatives [42]. These results are in line with those obtained in the present study.

It is a fact that people in a situation of dependency have additional expenses, which increase with the degree of the dependency, due to the technical aid required, the adjustments that need to be done in their homes, the hiring of caregivers, etc. The budget cuts on the Dependency Law [22] left those needs unmet. Therefore, according to the studies conducted to this respect, the total estimated cost of 4.193 billion hours of care provided by 1,326,270 informal carers in Spanish homes in 2008 would have posed an expenditure of 23.064 to 50.158 billion euros from the public administration, that is, between $2.1 \%$ and $4.6 \%$ of the gross domestic product of that year [43]. This fluctuation is due to the method used to estimate such cost. 
The PCDD and their families are forced to pay these expenses, with the subsequent repercussions on the health state (physical, psychological, and social) of the informal carers [44-46]. A comparative study carried out in the UK, United States, and Spain showed that the percentage of people with functional limitation who receive informal care is higher in Spain than in the other two countries. Moreover, such care is provided by people from outside of the family circle at a higher percentage in United States and the UK with respect to Spain [47]. All these studies, which are in line with the results obtained in the present study, also demonstrate that the family circle and the involvement of the family members in the provision of care constitute a fundamental support for PCDD.

Thus, the present study shows the importance of informal caregivers in the ethical, social, and economic scopes. Therefore, the public administrations and society in general must pay more attention to them and give them greater recognition.

The importance of the Dependency Law [22] became evident with the arrival of support for PCDD, who saw the satisfaction of previously unmet needs. However, due to the unequal implementation in the whole of Spain and the lack of budget allocation, the demand generated was not completely satisfied. The study of the Spanish Federation of Municipalities and Provinces [48] highlights that this has led to a constant increase in the waiting lists. This law was passed by the Spanish Parliament to provide a response to people who, due to their situation of dependency, require assistance to carry out the basic activities of daily living. This law regulates the attention to people in a situation of dependency through the creation of a system for autonomy and attention to dependency.

A country is considered to have an aged structure when the proportion of people of 60 years of age or older reaches $7 \%$. In the year 2019 , such percentage in Spain was $19.40 \%$, after a continuous increase from the year 2009, being the highest since the first records [9]. In addition to this, the dependency rate of the Spanish population over 64 years of age is $29.94 \%$ [49]. Some studies even predict that, in the year 2050, there will be in Europe more PCDD than people who can provide the care and support they need [50].

In view of these data and the results of the present study, actions and strategies should be designed and implemented to contribute to improving the assistance given to PCDD in their homes. The conditions of suffering from a chronic disease and being in a situation of dependency generate a series of needs that must be satisfied with the help of other people. To respond to this, the healthcare systems and social services need to ensure their capability to develop and coordinate multidimensional care models that include the necessary professionals who can meet the needs of PCDD, especially taking into account the demographic challenge and the aging of the population that society is facing. We need a model of attention focused on the person and based on the principles of the humanistic theory, in which the person is the center of any intervention, according to Maslow's hierarchy of human needs.

Although the definition of health provided by The World Health Organization has not been modified since the year 1948, the needs of the population have changed, as well as the expectations they generate regarding the healthcare systems and social services with respect to the support they will have to be able to provide. Therefore, further studies should be conducted in this research line to demonstrate these aspects.

This study shows that PCDD do not perceive that they have physiological unmet needs. They focus their requests on technical home assistance materials (adjustable beds and cranes, mostly) that facilitate the job of the people who provide the assistance service. Emotionally, their needs are related to their feeling of loneliness and their self-perception of being a "burden" to their relatives. Satisfying these needs implies an additional expense, which increases proportionally with the degree of dependency. All these perceptions are a cause of criticism against the current socio-sanitary system.

\section{Limitations}

This study shows the characteristic limitations of a qualitative study, thereby the data generated here cannot be extrapolated to other social and economic contexts due to the differences in the results 
that could derive from such extrapolation. Similarly, different results could be obtained if such study was carried out in the same environment but in a different time.

The fact that we recruited PCDD in day-care centers implies that the results could be different if the participants were permanently in their homes or coexisted with their children. Likewise, the results could be different if the participants' degree of dependency were mild.

\section{Conclusions}

The participants did not have unmet basic physiological needs. Their unmet needs were related to complex technical assistance material. In the emotional scope, their unmet psychological needs were generated by the loss of authority, clinging on to their homes, the feeling of loneliness, and the feeling of being a "burden" on their children. Socially, the needs they described were related to economic problems caused by the additional expenses derived from their situation of dependency and the lack or delay in the provision of public support.

Author Contributions: Conceptualization, O.M.L.-E., J.M.M.-L., M.S.-G., C.G.-R. and A.M.D.-M.-N.; Data curation, O.M.L.-E., J.M.M.-L., M.S.-G., C.G.-R. and A.M.D.-M.-N.; Formal analysis, O.M.L.-E. and J.M.M.-L.; Funding acquisition, J.M.M.-L.; Investigation, O.M.L.-E., J.M.M.-L., M.S.-G., C.G.-R. and A.M.D.-M.-N.; Methodology, J.M.M.-L. and C.G.-R.; Project administration, J.M.M.-L.; Resources, J.M.M.-L.; Supervision, J.M.M.-L.; Validation, O.M.L.-E. and J.M.M.-L.; Visualization, J.M.M.-L.; Writing—original draft, O.M.L.-E., J.M.M.-L., M.S.-G., C.G.-R. and A.M.D.-M.-N.; Writing-review \& editing, O.M.L.-E., J.M.M.-L., M.S.-G., C.G.-R. and A.M.D.-M.-N. All authors have read and agreed to the published version of the manuscript.

Funding: This study was carried out with funds received from winning the 2nd prize of the 1st Andalusian Call of Awards for Projects of Social Research and Innovation "Luisa Martínez", organized by the Ageing Lab Foundation, and sponsored by CaixaBank and Macrosad, in collaboration with the Provincial Deputation of Jaén and the Andalusian Agency for Social Services and Dependency.

Conflicts of Interest: The authors declare no conflicts of interest.

\section{References}

1. World Health Organization. Temas de Salud. Enfermedades Crónicas. 2012. Available online: http: //www.who.int/topics/chronic_diseases/es/ (accessed on 27 December 2019).

2. Palladino, R.; Pennino, F.; Finbarr, M.; Millett, C.; Triassi, M. Multimorbidity and Health Outcomes in Older Adults in Ten European Health Systems, 2006-2015. Health Aff. 2019, 38, 613-623. [CrossRef] [PubMed]

3. World Health Organization. Marco Mundial de Vigilancia Integral Para la Prevención y el Control de las Enfermedades no Transmisibles 2019. Available online: https://www.who.int/nmh/global_monitoring framework/es/ (accessed on 15 December 2019).

4. Instituto Nacional de Estadística. Encuesta Europea de Salud. 2014. Available online: http://www.ine.es/ prensa/np937.pdf (accessed on 27 December 2019).

5. Manning, D.L.; Dickens, C. Health literacy: More choice, but do cancer patients have the skills to decide? Eur. J. Cancer Care 2006, 15, 448-452. [CrossRef] [PubMed]

6. Tang, Y.H.; Pang, S.M.; Chan, M.F.; Yeung, G.S.; Yeung, V.T. Health literacy, complication awareness, and diabetic control in patients with type 2 diabetes mellitus. J. Adv. Nurs. 2007, 62, 74-83. [CrossRef]

7. Cruz, M.; Pérez, M.C.; Jenaro, C.; Torres, E.A.; Cardona, E.I.; Vega, V. Discapacidad, Cronicidad y Envejecimiento: La Emergencia del Cuidado Ante la Dependencia. Index Enfermería 2017, 26, 53-57.

8. Instituto Nacional de Estadística. Indicadores de Estructura de la Población. Resultados nacionales. Tasa de Dependencia. 2019. Available online: https:/www.ine.es/jaxiT3/Tabla.htm?t=1419\&L=0 (accessed on 3 January 2020).

9. Instituto Nacional de Estadística. Indicadores de Estructura de la Población. Resultados nacionales. Proporción de Personas Mayores de Cierta Edad. 2019. Available online: https://www.ine.es/jaxiT3/Datos. $\mathrm{htm}$ ? $=1417$ (accessed on 3 January 2020).

10. Vidal, M.J.; Labeaga, J.M.; Casado, P.; Madrigal, A.; López, J.; Montero, A.; Meil, G. Informe 2016 Las Personas Mayores en España. Available online: https://www.imserso.es/InterPresent1/groups/imserso/documents/ binario/112017001_informe-2016-persona.pdf (accessed on 11 April 2020). 
11. Carr, W.; Wolfe, S. Unmet needs as sociomedical indicators. Int. J. Health Serv. 1976, 6, 417-430. [CrossRef] [PubMed]

12. Ronksley, P.E.; Sanmartin, C.; Quan, H.; Ravani, P.; Tonelli, M.; Manns, B.; Hemmelgarn, B.R. Association between perceived unmet health care needs and risk of adverse health outcomes among patients with chronic medical conditions. Open Med. 2013, 7, e21-e30. [PubMed]

13. McCusker, J.; Roberge, D.; Levesque, J.F.; Ciampi, A.; Vadeboncoeur, A.; Larouche, D.; Sanche, S. Emergency department visits and primary care among adults with chronic conditions. Med. Care 2010, 48, 972-980. [CrossRef]

14. Zuckerman, S.; Shen, Y.C. Characteristics of occasional and frequent emergency department users: Do insurance coverage and access to care matter? Med. Care 2004, 42, 176-182. [CrossRef]

15. Allin, S.; Grignon, M.; Le Grand, J. Subjective unmet need and utilization of health care services in Canada: What are the equity implications? Soc. Sci. Med. 2010, 70, 465-472. [CrossRef]

16. Tong, A.; Sainsbury, P.; Craig, J. Consolidated criteria for reporting qualitative research (COREQ): A 32-item checklist for interviews and focus groups. Int. J. Qual. Health Care 2007, 19, 349-357. [CrossRef]

17. Creswell, J. Qualitative Inquiry and Research Design: Choosing among Five Approaches, 3rd ed.; Sage: Los Angeles, CA, USA, 2013.

18. Ward, G.; Dixon, H. The research masters experience: The impact of efficacy and outcome expectations on enrolment and completion. J. Furth. High. Educ. 2014, 38, 163-181. [CrossRef]

19. Lincoln, Y.S.; Guba, E.G. Naturalistic Inquiry; Sage: Los Angeles, CA, USA, 1985.

20. Mahoney, F.L.; Barthel, D.W. Functional evaluation: The Barthel Index. Md. State Med. J. 1965, 14, 61-65. [PubMed]

21. Baztán, J.J.; Pérez-del-Molino, J.; Alarcón, T.; San Cristóbal, E.; Izquierdo, G.; Manzarbeitia, J. Índice de Barthel: Instrumento válido para la valoración funcional de pacientes con enfermedad cerebrovascular. Rev. Española Geriatr Gerontol. 1993, 28, 32-40.

22. Boletín Oficial del Estado. Ley 39/2006, de 14 de diciembre, de Promoción de la Autonomía Personal y Atención a las personas en situación de dependencia. Available online: https://www.boe.es/buscar/act.php? id=BOE-A-2006-21990 (accessed on 12 July 2018).

23. Morse, J.M. “Data were satured”. Qual. Health Res. 2015, 25, 587-588. [CrossRef] [PubMed]

24. McLenan, S.R.; Diebold, M.; Rich, L.E.; Elger, B.S. Nurses's perspectives regarding the disclosure of errors to patients: A qualitative study. Int. J. Nurs. Stud. 2016, 54, 16-22. [CrossRef] [PubMed]

25. Braun, V.; Clarke, V. Using thematic analysis in psychology. Qual. Res. Psychol. 2006, 3, 77-101. [CrossRef]

26. Nowell, L.S.; Norris, J.M.; White, D.E.; Moules, N.J. Thematic Analysis: Striving to Meet the Trustworthiness Criteria. Int. J. Qual. Methods 2017, 16, 1-13. [CrossRef]

27. World Health Organization. Summary report on proceedings minutes and final acts. In International Health Conference; World Health Organization: New York, NY, USA, 1948.

28. Engel, G. The need for a new medical model: A challenge for biomedicine. Science 1977, 196, 129-136. [CrossRef]

29. Gómez, R.; Fernández, C.; Cámara, N. Quién cuida a quién? La disponibilidad de cuidadores informales para personas mayores en España. Una Aproximación Demográfica Basada en Datos de Encuesta. Available online: http://envejecimiento.csic.es/documentos/documentos/enred-info20-quiencuida. pdf (accessed on 12 January 2020).

30. Zalakain, J. Atención a la dependencia en la UE: Modelos, tendencias y retos. Rev. Derecho Soc. Y Empresa 2017, 8, 19-39.

31. Franco, P.; Ruiz, B. El trabajo de ayuda a domicilio en España. Available online: http://www.ugt.es/sites/ default/files/el_trabajo_de_ayuda_a_domicilio_ugt_fesp_sep_2018_def_0.pdf (accessed on 12 January 2020).

32. Instituto de Mayores y Servicios Sociales. La participación social de las Personas Mayores. Available online: https://www.imserso.es/InterPresent2/groups/imserso/documents/binario/11005partsocialmay.pdf (accessed on 12 January 2020).

33. Malagón, J.L. La integración sociofamiliar de los mayores. Esc. Abierta 1999, 3, 89-101.

34. Anaut, S.; Caparrós, N.; Calvo, J.J. Personas Mayores y Exclusión Social. Available online: https://www. unavarra.es/digitalAssets/168/168636_10000003-Personas-mayores-y-exclusion-social-PDF.pdf (accessed on 15 December 2019). 
35. Instituto Nacional de Estadística. Encuesta Continua de Hogares Año. 2018. Available online: https: //www.ine.es/prensa/ech_2018.pdf (accessed on 3 January 2020).

36. Cole, S.W.; Capitanio, J.P.; Chun, K.; Arevalo, J.M.G.; Ma, J.; Cacioppo, J.T. Myeloid differentiation architecture of leukocyte transcriptome dynamics in perceived social isolation. Proc. Natl. Acad. Sci. USA 2015, 112, 15142-15147. [CrossRef]

37. Rico, L.A.; Caballero, F.F.; Olaya, B.; Tobiasz, B.; Koskinen, S.; Leonardi, M.; Haro, J.M.; Chatterji, S.; Ayuso-Mateos, J.L.; Miret, M. Loneliness, Social Networks, and Health: A Cross-Sectional Study in Three Countries. PLoS ONE 2016, 11, e0145264. [CrossRef]

38. Losada, A.; Márquez-González, M.; García-Ortiz, L.; Gómez-Marcos, M.A.; Fernández-Fernández, V.; Rodríguez-Sánchez, E. Loneliness and mental health in a representative sample of community-dwelling Spanish older adults. J. Psychol. Interdiscip. Appl. 2012, 146, 277-292. [CrossRef]

39. World Health Organization. Informe Mundial Sobre el Envejecimiento y la Salud. 2015. Available online: https:/apps.who.int/iris/bitstream/handle/10665/186466/9789240694873_spa.pdf;jsessionid= 7980E6846BC3266230C7C7BD9624BC11?sequence=1 (accessed on 12 January 2020).

40. McPherson, C.J.; Wilson, K.G.; Murray, M.A. Feeling like a burden: Exploring the perspectives of patients at the end of life. Soc. Sci. Med. 2007, 64, 417-427. [CrossRef] [PubMed]

41. Rurup, M.L.; Pasman, H.R.W.; Goedhart, J.; Deeg, D.J.H.; Kerkhof, A.J.F.M.; Onwuteaka-Philipsen, B. Understanding why older people develop a wih to die: A qualitative interview study. Crisis 2011, 32, $204-216$. [CrossRef] [PubMed]

42. Dugow, H.; Connolly, D. Exploring impact of independent living programme on activity participation of elderly people with chronic condictions. Int. J. Ther. Rehabil. 2012, 19, 154-162. [CrossRef]

43. Oliva-Moreno, J.; Peña-Longobardo, L.M.; Vilaplana-Nieto, C. An estimation of the value of informal care provided to dependent people in Spain. Appl. Health Econ. Health Policy 2015, 13, 223-231. [CrossRef]

44. García-Calvente, M.M.; Mateo-Rodríguez, I.; Maroto-Navarro, G. El impacto de cuidar en la salud y la calidad de vida de las mujeres. Gac Sanit. 2004, 18 (Suppl. 2), 83-92. [CrossRef]

45. Larrañaga, I.; Martín, U.; Bacigalupe, A.; Begiristáin, J.M.; Valderrama, M.J.; Arregi, B. Impacto del cuidado informal en la salud y la calidad de vida de las personas cuidadoras: Análisis de las desigualdades de género. Gac. Sanit. 2008, 22, 443-450. [CrossRef]

46. Vicente, M.A.; de la Cruz, C.; Morales, R.A.; Martínez, C.M.; Villareal, M.A. Cansancio, cuidados y repercusiones en cuidadores informales de adultos mayores con enfermedades crónico degenerativas. Eur. J. Investig. Health 2014, 4, 151-160. [CrossRef]

47. Solé-Auró, A.; Crimmins, E.M. Who cares? A comparison of informal and formal care provision in Spain, England and the USA. Ageing Soc. 2014, 34, 495-517. [CrossRef]

48. Federación Española de Municipios y Provincias. La situación del Servicio de Ayuda a Domicilio en el ámbito Local y Perspectivas de Futuro. Available online: https://www.fundacioncaser.org/sites/default/files/ adjuntos/librosad_completo_web.pdf (accessed on 20 January 2020).

49. Instituto Nacional de Estadística. Indicadores de Estructura de la Población. Resultados nacionales. Tasa de Dependencia de la población mayor de 64 años. 2019. Available online: https://www.ine.es/jaxiT3/Tabla. htm?t=1421\&L=0 (accessed on 3 January 2020).

50. Lipszyc, B.; Sail, E.; y Xavier, A. Long-term care: Need, use and expenditure in the EU-27. Economic Papers (Vol. 469). Available online: https://ec.europa.eu/economy_finance/publications/economic_paper/2012/pdf/ ecp469_en.pdf (accessed on 20 January 2020).

(C) 2020 by the authors. Licensee MDPI, Basel, Switzerland. This article is an open access article distributed under the terms and conditions of the Creative Commons Attribution (CC BY) license (http://creativecommons.org/licenses/by/4.0/). 